\title{
Investigation of Antioxidant Properties and Bioactive Composition of Allium tuncelianum ((Kollman) Ozhatay, Matthew \& Siraneci) and Allium sativum L.
}

\author{
Müşerref Hilal ŞEHITOĞLU ${ }^{1,}$ Faika YARALI KARAKAN² ${ }^{2}$ Bayram KIZILKAYA, Rahime Özlem ÖZTOPUZ4, \\ İlhami GÜLÇìN ${ }^{5}$
}

\begin{abstract}
In the present study, the extracts of Allium tuncelianum and Allium sativum L. were evaluated for antioxidant capacities, fatty acid, amino acid and phenolic compositions. In order to evaluate the antioxidant capacity of the extracts, total antioxidant amount, radical scavenging and chelating activities, reducing power by cupric reducing antioxidant capacity and ferric reduction antioxidant power methods were performed and compared with reference antioxidants. Quantitative amounts of phenolic compounds were determined by the liquid chromatography-mass spectrometry. Gas chromatography-mass spectrometry and high performance liquid chromatography methods were used for the fat / fatty acid and amino acid compositions, respectively. The content of p-Coumaric acid in Tunceli garlic was found higher compared to the cultuvated garlic. Total antioxidant capacity $\mathrm{IC}_{50}$ values were determined in Tunceli garlic as $72.20 \mu \mathrm{g} \mathrm{ml}^{-1}$; in cultuvated garlic as $63.80 \mu \mathrm{g} \mathrm{ml}^{-1}$. In terms of fatty acid compositions, Tunceli garlic $(\omega-3,3.92 \%$; $\omega-6,46.91 \% ; \omega-9,14.16 \%)$ was observed having more effective level of essential omega acids compared to the cultuvated garlic $(\omega-3,3.20 \% ; \omega-6,50.37 \% ; \omega-9,5.18 \%)$. According to essential amino acid contents, the Tunceli garlic was found to be richer than cultuvated garlic. As a result, due to the high biological activity of Tunceli garlic, it would be more beneficial in diet, in terms of cancer and cardiovascular disease treatment.
\end{abstract}

Keywords: Allium tuncelianum, Allium sativum L., antioxidant capacity, essential fatty acids, amino acid.

\section{Allium tuncelianum ((Kollman) Özhatay, Matthew \& Şiraneci)) ve Allium sativum L.'nın Antioksidan Özelliklerinin ve Biyoaktif Bileşimlerinin İncelenmesi}

\begin{abstract}
ÖZET: Bu çalışmada Allium tuncelianum ve Allium sativum L. ekstraktlarının antioksidan ve antiradikal kapasiteleri, yağ asidi, amino asit ve fenolik kompozisyonları araştırılmıştır. Ekstraktların antioksidan kapasitelerini değerlendirmek için total antioksidan kapasiteleri, radikal giderme ve metal şelatlama aktiviteleri, kuprik ve ferrik iyonlarını indirgeme metotları uygulanmış ve referans antioksidanlarla karşılaştııılmıştır. Fenolik bileşiklerin kantitatif miktarları, sıvı kromatografisi-kütle spektrometresi ile belirlenmiştir. Yağ/yağ asidi ve amino asit bileşimleri için sırasıyla gaz kromatografisi-kütle spektrometresi ve yüksek performanslı sıvı kromatografisi yöntemleri kullanıldı. Tunceli sarımsındaki p-Kumarik asit içeriği kültür sarımsağına oranla daha yüksek bulunmuştur. Toplam antioksidan kapasite $\mathrm{IC}_{50}$ değerleri Tunceli sarımsağında $72.20 \mu \mathrm{g} \cdot \mathrm{ml}^{-1}$ olarak belirlenirken kültür sarımsağ 1 için bu değer $63.80 \mu \mathrm{g} \mathrm{ml}^{-1}$ olarak bulunmuştur. Yağ asit bileşimleri açısından, Tunceli sarımsağı ( $\omega-3, \% 3.92 ; \omega-6$, \%46.91; $\omega-9, \% 14.16)$, kültür sarımsağı ile karşılaştırıldığında, daha etkili bir temel omega asit düzeyine sahip olduğu gözlendi $(\omega-3, \% 3.20 ; \omega-6, \% 50.37 ; \omega-9, \% 5.18)$. Esansiyel amino asit içeriğine göre, Tunceli sarımsağı, kültür sarımsağından daha zengin bulunmuştur. Sonuç olarak, Tunceli sarımsağının yüksek biyolojik aktivitesi nedeniyle, kanser ve kardiyovasküler hastalıkların tedavisi açısından diyette daha yararlı olacaktır.
\end{abstract}

Anahtar Kelimeler: Allium tuncelianum, Allium sativum L., antioksidan kapasite, esansiyel yağ asitleri, amino asit.

\footnotetext{
Müşerref Hilal ŞEHITOĞLU (0000-0003-4436-9160), Çanakkale Onsekiz Mart Üniversitesi, Tıp Fakültesi, Temel Tıp Bilimleri Bölümü, Çanakkale, Türkiye

Faika YARALI KARAKAN (0000-0002-2176-8663), Kilis 7 Aralık Üniversitesi, Ziraat Fakültesi, Bahçe Bitkileri Bölümü, Kilis, Türkiye Bayram KIZILKAYA (0000-0002-3916-3734), Çanakkale Onsekiz Mart Üniversitesi, Deniz Bilimleri Fakültesi, Su Ürünleri Yetiştiriciliği Bölümü, Çanakkale, Türkiye

4 Rahime Özlem ÖZTOPUZ (0000-0002-1373-6311), Çanakkale Onsekiz Mart Üniversitesi, Tıp Fakültesi, Temel Tıp Bilimleri Bölümü, Çanakkale, Türkiye

İlhami GÜLÇİN (0000-0001-5993-1668), Atatürk Üniversitesi, Fen Fakültesi, Kimya Bölümü, Erzurum, Türkiye

Sorumlu yazar/Corresponding Author: Müşerref Hilal ŞEHITOĞLU, hill_al@ hotmail.com
} 


\section{INTRODUCTION}

Free radicals have important effects on important compounds such as lipids, proteins, DNA, carbohydrates and enzymes in cells. Superoxide radical $\left(\mathrm{O}_{2}^{-}\right)$and hydroxyl radical $(\mathrm{OH} \bullet)$ initiate lipid peroxidation in cytoplasm, mitochondria, nucleus and endoplasmic reticulum membranes. Lipid peroxidation in membranes results in increased membrane permeability. Cell damage is the result of all these effects of free oxygen radicals (Altinisik, 2000; Loeckie, 1999; Dizdaroglu, 1991). There are many defense mechanisms in combination with antioxidant defense systems to prevent the formation of reactive oxygen species (ROS) and their damage. Antioxidant compounds that act as shields in our bodies neutralize free radicals by giving their electrons without converted into free radicals. (Davies, 1995; Prior and Cao, 2000). Antioxidant molecules structures usually carry phenolic function (Kahkonen et al., 1999). Phenolic antioxidants function as free radical scavengers and metal chelators. Allium sativum L. (AS) has been used as a herbal medicine for thousands of years as well as for use in world cuisines (Rivlin, 2001). Epidemiological studies in recent years have revealed an inverse relationship between garlic consumption and the incidence of cancer types, including stomach, colon and laryngeal cancers (Buiatti et al., 1991, Mei et al., 1989, Steinmetz et al., 1994, Sumiyoshi and Wargovich, 1990; Zheng et al., 1992). Allium tuncelianum (AT) is an endemic plant species that is widespread in the Ovacık and Pülümür districts in only the province of Tunceli and especially in the foothills of Munzur mountains in the World. Allium Tuncelianum called as Tunceli garlic, with singlethreaded, small tooth-like formations between the crusts above, has a known mild garlic odour and flavor. In animal experiments and clinical trials, it has been shown that garlic and its components have multiple beneficial effects such as an antimicrobial (Ankri and Mirelman, 1999), anti-cancer (Lan and Lu, 2004; Xiao et al., 2006; Seki et al., 2008; Antony and Singh, 2011), heart protection against ischemia/reperfusion (Sener et al., 2007; Mukherjee et al., 2009), reduction of serum cholesterol (Antony and Singh, 2011), inhibition of angiogenesis (Xiao et al. 2006; Ried et al., 2010), including thrombolysis (Rahman, 2001) and at the same time anti-arrhythmic (Martin et al., 1994). Considering that it has antioxidant and antiradical activity due to the polyphenol compounds, essential fatty acids and amino acid contained in the garlic plant, Allium tuncelianum an endemic species, has a stronger antioxidant and antiradical activity than Allium sativum L.. It is thought that the results obtained by comparing antioxidant and radical elimination activities between two garlic species within this study will contribute to the design and pharmacological applications of the drugs to be used for the treatment.

\section{MATERIAL AND METHOD}

\section{Extraction of Garlics}

Garlic heads from cultivated garlic, Allium sativum L. (AS) and Allium Tuncelianum (Kollman) Ozhatay, Matthew \& Siraneci (AT) were used in the research. The headings of Allium Tuncelianum were obtained from Tunceli province. The air dried and pulverized garlic samples $(100 \mathrm{~g})$ were extracted three times with $300 \mathrm{ml}$ of methanol for 24 hours at room temperature. The solvent was removed in vacuo at $30^{\circ} \mathrm{C}$ in a rotary evaporator until dry methanol extracts $(15.6 \%$ yield $)$ were obtained.

\section{Antioxidant Studies}

The $\mathrm{Cu}^{2+}$ reduction activities of AT and AS were made with a slight modification of the copper ion reduction method based on absorbance measurement at $450 \mathrm{~nm}$ (Apak et al., 2006; Ak and Gülcin, 2008). Ferric reducing antioxidant power (FRAP) method is based upon the reduction of $\mathrm{Fe}^{3+}$-TPTZ complex under acidic medium and situations. Enhanced absorbance of the blue-colored ferrous form ( $\mathrm{Fe}^{2+}-\mathrm{TPTZ}$ complex) is determined at $593 \mathrm{~nm}$ (Gülçin, 2006). $\mathrm{Fe}^{2+}$ chelating activity of samples were spectrophotometrically determined at $522 \mathrm{~nm}$ by using bipyridyl according to Re et al. (1999). Superoxide anion radical scavenging effect of AT and AS was determined by spectrophotometric measurement of nitroblue tetrazolium (NBT) product (Zhishen et al., 1999). After all procedure absorbance values was measured at $560 \mathrm{~nm}$. Determination of $\mathrm{n}, \mathrm{n}>$-dimethyl-p-phenylenediamine dihydrochloride (DMPD) radical scavenging activity of AT and AS were performed as Foglina et al. have done before (1999). Firstly, a colored radical cation (DMPD ${ }^{+}$) was obtained and added to sample tubes of AS, AT and standard antioxidants. After an incubation the absorbance was measured at $505 \mathrm{~nm}$. Total antioxidant activity of AT 
and AS was determined by measuring of the absorbance at $500 \mathrm{~nm}$ according to the thiocyanate method (Yen and Chen, 1995).

\section{Analytical Studies}

\section{LC-MS / MS instrumentation and chromatog- raphic conditions}

Dry filtrates were diluted to $1000 \mathrm{mg} / \mathrm{L}$ and prefiltered with a 0.2 micron microfiber filter for LC-MS/ MS analysis. LC-MS / MS analysis of the AS and AT was performed using a Nexera model Shimadzu UHPLC coupled with dual MS instrument. The liquid chromatograph is equipped with LC-30AD dual pump, DGU-20A3R degasser, KTO-10Avp column furnace and SIL-30AC automatic sampler. Chromatographic separation was performed on a $\mathrm{C} 18$ reverse-phase Inertsil ODS-4 (150 mm x $4.6 \mathrm{~mm}, 3 \mathrm{um})$ analytical column. The column temperature is fixed at $40{ }^{\circ} \mathrm{C}$. The dilution tendency is composed of mobile phase A (water, $5 \mathrm{mM}$ ammonium formate and $0.1 \%$ formic acid) and mobile phase B (methanol, $5 \mathrm{mM}$ ammonium formate and $0.1 \%$ formic acid). With different ratios of solvent $\mathrm{B}$, the gradient program was $\mathrm{t}$ (minute): $\mathrm{B} \%$.

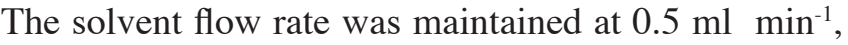
and the injection volume was maintained at $4 \mathrm{uL}(20$, 90), (23,99, 90), (24,40) (Ertas et al., 2015).

\section{MS instrumentation}

MS detection was performed using a triple fourpole mass spectrometer equipped with an ESI source measuring both positive and negative ionisation modes, Shimadzu LCMS 8040 model. LC-MS / MS data were collected and then processed with LabSolutions software (Shimadzu, Kyoto, Japan). The multi-reaction follow-up (MRM) mode was used to measure the analysis, and the analysis of the investigated compounds was performed following two or three passes per compound. The second is for quantitative purposes, the second is for approval, and / or the third is for approval.

\section{Analysis of the fatty acids}

The crude oil analysis was based on the method of IUPAC (1987) and Erickson (1993). Samples were homogenized with methanol/chloroform (1/2). The fatty acids were methylated with $\mathrm{BF}_{3}: \mathrm{MeOH}$ and the resulting esters were analyzed. Fatty acid compositions were determined with Shimadzu Gas Chromatography (GC-2010).

\section{Determination of amino acid contents}

For amino acid profiles, the dried samples were hydrolysed at $110^{\circ} \mathrm{C}$ for 24 hours with $6.0 \mathrm{M}$ hydrochloric acid. The hydrolysates of samples were filtered through a PTFE syringe filter, and then the hydrochloric acid in solutions was evaporated. After evaporation, the hydrolysates samples were dissolved in citrate-sodium citrate buffer (0.1 M, pH 2.2) (Srivastava et al., 2006; Chi et al., 2008). Amino acid contents were performed using HPLC according to Arrieta et al. (2012). The method is based on the measurement of the amino acids derivatized with OPA (orthophtalaldehyde) by fluorescence detector.

\section{RESULTS AND DISCUSSION}

Research in recent years has determined many types of biological activity due to the bioactive components contained in garlic. Especially with the antioxidant activities of phenolic compounds, these natural compounds have been shown to have cancer-protective properties. In the current study, the antioxidant and antiradical activities of the endemic species of AT and for comparison AS were determined using different bioanalytical methods. A variety of studies have revealed that problems occurring in chronic diseases and development are closely associated with the termination of free radical development.

As a result of tissue damage, cells with phagocyte activation or lysis release transition metal ions causing free oxygen species to form. Free oxygen radicals are deactivated by oxidizing thiol groups in amino acids found in enzyme and protein structures. Additionally, polyunsaturated fat acids found in cell membranes may be oxidized causing cell injury (Haugaard, 1968; Pacific et al., 1991). In this study considering the effect mechanisms of antioxidants to prevent injury caused by transition metals, the reducing capacities of two allium species with high antioxidant effect for iron and copper ions were assessed. The reduction capacity of $\mathrm{Cu}^{2+}$ of AT and AS is increasing in direct proportion to the concentration of solutions. Absorbance values were compared to each other as given in Table 1, after plotting the reduction curves of $\mathrm{Cu}^{2+}$ and $\left(\mathrm{Fe}^{3+}\right.$ ions. The comparison of $\mathrm{Cu}^{2+}$ reducing power; $\mathrm{BHA}>\mathrm{BHT}>$ Trolox $>\alpha$-Tocopherol $>$ AT $>$ AS. The comparison of $\mathrm{Fe}^{3+}$ reducing power; BHA $>\alpha$-Tocopherol $>$ BHT $>$ 
Trolox $>$ AS $>$ AT. The reduction potential for $\mathrm{Cu}^{2+}$ to $\mathrm{Cu}^{+}$was observed to be highest for AT within the garlic samples. The reason for this is thought to be the $\mathrm{OH}$ group linked to the aromatic ring in the p-coumaric molecules contained in AT. According to the FRAP method, the reducing capacity is based on reduction of $\mathrm{Fe}^{3+}$. In the present study when the FRAP activities of the garlic samples are investigated, there appeared to be no significant difference between AS and AT.

Table 1. Ferric ion $\left(\mathrm{Fe}^{3+}\right)$ and cupric $\left(\mathrm{Cu}^{2+}\right.$ ion reduction capacities of Allium tuncelianum and Allium sativum $\mathrm{L}$. at a concentration of $20 \mu \mathrm{g} / \mathrm{ml}$ and comparison with BHA, BHT, $\alpha$-tocopherol, and trolox, which are the standard antioxidants

\begin{tabular}{lcc}
\hline Samples & $\begin{array}{c}\text { Absorbance } \\
\mathbf{( 4 5 0} \mathbf{~ n m})\end{array}$ & $\begin{array}{c}\text { Absorbance } \\
\mathbf{( 5 9 3} \mathbf{~ n m})\end{array}$ \\
\hline BHA & 0,547 & 2,154 \\
\hline BHT & 0,436 & 1,120 \\
\hline$\alpha$-Tocopherol & 0,369 & 1,224 \\
\hline Trolox & 0,402 & 0,828 \\
\hline Allium sativum L. & 0,075 & 0,426 \\
\hline Allium tuncelianum & 0,084 & 0,403 \\
\hline
\end{tabular}

In our study the metal chelating activities of extracts were found to be $5.3 \mu \mathrm{g} \mathrm{ml}^{-1}$ for AT and 6.57 $\mu \mathrm{g} \mathrm{ml}{ }^{-1}$ for $\mathrm{AS}$ at $\mathrm{IC}_{50}$ values. The bipyridyl metal ions chelating activities; AT> AS> Trolox> BHT> $\alpha$-Tocopherol> BHA. The metal chelating activities of the garlic samples used in the study were $5-7 \mu \mathrm{g} \mathrm{ml}^{-1}$ at $\mathrm{IC}_{50}$ values, while the metal chelating activities of natural antioxidants like $\alpha$-hederin, hederasaponin $\mathrm{C}$, hederacolchiside $\mathrm{E}$ and hederacolchiside $\mathrm{F}$ were found to be $51,53,71$ and $61 \mu \mathrm{g} / \mathrm{ml}$ at $\mathrm{IC}_{50}$ values (Gülcin et al., 2004). The metal chelating activity of garlic samples, especially AT, were found to be higher than these materials listed as very effective in the literature. Superoxide anions have the potential for reaction with biological macro molecules and are precursors of active free radicals and thus, cause tissue damage (Halliwell and Gutteridge, 1984). The superoxide anion radical scavenging activities of AT and AS compared to the standard antioxidants, respectively as follows; AT $>$ $\alpha$-Tocopherol $>$ BHA $>$ BHT $\approx$ Trolox $>$ AS.

The radical scavenging method used in experimental studies is DMPD ${ }^{+}$scavenging activity. DMPD $^{*+}$ (N,N-dimethyl-p-phenylene diamine) is another test very similar to ABTS ${ }^{*+}$ use (Fogliano et al., 1999). AT, AS and the standard antioxidant molecules used exhibited DMPD ${ }^{\circ+}$ removal activity, respectively, as follows: Trolox $>$ BHA $>$ AT $>$ BHT $>\alpha$-Tocopherol $>>$
AS as seen in Table 2. The AT extract garlic samples used in the study had more effective activity for DMPD + scavenging activity than BHT and especially a-tocopherol compounds used as standards.

When other studies in the literature are examined, both garlic samples were observed to be more effective compared to other materials. The $\mathrm{IC}_{50}$ value for L-adrenaline was $15.6 \mu \mathrm{g} \mathrm{ml}^{-1}$ (Gülcin, 2009) and for curcumin was $34.5 \mu \mathrm{g} \mathrm{ml}^{-1}$ (Ak and Gülcin, 2008). The $\mathrm{IC}_{50}$ value of $14.84 \mu \mathrm{g} \mathrm{ml}^{-1}$ found for AT shows it has higher activity than adrenaline.

Total antioxidant capacity is a common parameter used for food and medical bioactive compounds. It describes the property of the compound used with the aim of preventing oxidative destruction like lipid peroxidation (Roginsky and Lissi, 2005). Antioxidant activity was found to be directly proportional to the increasing amount of AT and AS. The absorbance at $500 \mathrm{~nm}$ of the standard antioxidants, AT and AS were measured in the same way. The amount of inhibition of peroxidation by linoleic acid emulsion was $63.8 \%$ for Allium sativum L., $72.2 \%$ for Allium Tuncelianum, $91.9 \%$ for trolox and $83.8 \%$ for $\alpha$-tocopherol. Accordingly, when the total antioxidant activity capacity of the samples is compared: Troloxy $>$ BHT> BHA $>\alpha$-Tocopherol $>$ AT $>$ AS 
Table 2. The $\mathrm{IC}_{50}$ values of metal chelating and radical scavenging activities of Allium tuncelianum and Allium sativum L. compared to standard antioxiants, BHA, BHT, $\alpha$-tocopherol and trolox and percent inhibition of peroxidation of linoleic acid emulsion at $30 \mu \mathrm{g} \mathrm{ml}{ }^{-1}$ and 48 hours.

\begin{tabular}{|c|c|c|c|c|}
\hline Samples & $\begin{array}{l}\text { Bipyridyl metal } \\
\text { chelating activity } \\
{\left[\mathrm{IC}_{50}\right]\left(\mu \mathrm{g} \mathrm{m}^{-1}\right)}\end{array}$ & $\begin{array}{l}\text { Superoxide anion radical } \\
\left(\mathrm{O}_{2}^{-}\right) \text {scavenging activity } \\
{\left[\mathrm{IC}_{50}\right]\left(\mu \mathrm{g} \mathrm{ml}^{-1}\right)}\end{array}$ & $\begin{array}{l}\mathrm{DMPD}^{\circ+} \text { radical } \\
\text { scavenging activity } \\
{\left[\mathrm{IC}_{50}\right]\left(\mu \mathrm{g} \mathrm{ml}^{-1}\right)}\end{array}$ & $\begin{array}{l}\text { Total antioxidant } \\
\text { activity-\% Removal } \\
\left(30 \mu \mathrm{g} \mathrm{m}^{-1}-48 \mathrm{~h}\right)\end{array}$ \\
\hline BHA & 28.45 & 19.51 & 13.93 & 89.90 \\
\hline BHT & 8.03 & 20.68 & 14.84 & 90.00 \\
\hline$\alpha$-Tocopherol & 16.26 & 17.51 & 15.17 & 83.80 \\
\hline Trolox & 7.27 & 20.69 & 11.77 & 91.90 \\
\hline Allium Sativum $\mathbf{L}$ & 6.57 & 24.39 & 17.07 & 63.80 \\
\hline Allium Tuncelianum & 5.30 & 12.88 & 14.84 & 72.20 \\
\hline
\end{tabular}

Biosynthesis of phenolic compounds is very complicated. The reaction chain starting with phosphenoenolpyruvic acid, progresses from the tyrosine to the formation of the p-Coumaric acid while phenylalanine provides cinnamic acid products. Cinnamic acid transforms sequentially to p-coumaric acid, caffeic acid, ferulic acid and cinnapic acid (Harborne, 1964). When the phenolic and organic acid components of AS and AT were analyzed according to
LC MS / MS method, Malic acid amount of AT, it is seen that the amount of malic acid in AT is more than AS. It is also seen that, the $\rho$-coumaric acid amount in AT especially (102.39 $\mu \mathrm{g}$ analyte $\left.\mathrm{g}_{\text {extract }}{ }^{-1}\right)$ was higher than AS (54.60 $\mu$ g analyte g extract $\left.{ }^{-1}\right)$ supporting the higher antioxidant capacity. Phenolic and organic compounds not present in the AS and AT contents have not been included in the table 3 .

Table 3. Amounts of phenolic and organic acid compounds in Allium tuncelianum and Allium sativum L. $\left(30 \mu \mathrm{g} \mathrm{ml}^{-1}\right)$

\begin{tabular}{lll}
\hline Sample & AT- MeOH & AS -MeOH \\
\hline Quinic acid & 46712.74 & 70381.84 \\
\hline Malic acid & 17804.44 & 15929.51 \\
\hline tr-Aconitic acid & 2179.47 & 4624.23 \\
\hline Vanillin & 44.53 & 172.80 \\
\hline p-Coumaric acid & 102.39 & 54.60 \\
\hline Rhamnetin & N.D & 49.24 \\
\hline
\end{tabular}

ND: Not Dedected

When fat analysis is investigated, the amount of unsaturated fat acids in AT was $66.4 \%$ while in AS it was $59.64 \%$. Similarly, when the saturated fat acid amounts are investigated, AT had slightly lower rates of saturated fat acid at $33.39 \%$ while AS had $40.36 \%$. Results of crude oil analysis of AT and AS were found as $3.07 \pm 0.12$ and $2.02 \pm 0.09$, respectively. The fatty acid contents results of AT and AS were as given in Table 4. 
Müşerref Hilal ŞEHITOĞLU et al.

Table 4. Fatty acid contents of Allium tuncelianum and Allium sativum L. extracts

\begin{tabular}{|c|c|c|}
\hline Fatty Acid & AT (\%) & AS (\%) \\
\hline C6:0 & 0.76 & 0.98 \\
\hline $\mathrm{C} 8: 0$ & ND & ND \\
\hline C10:0 & ND & 0.30 \\
\hline C11:0 & 0.32 & 0.22 \\
\hline C12:0 & 0.65 & 0.37 \\
\hline C13:0 & 0.29 & 0.37 \\
\hline $\mathrm{C} 14: 0$ & 0.50 & 0.60 \\
\hline C14:1 & ND & ND \\
\hline C15:0 & 0.23 & 0.33 \\
\hline C15:1 & $\mathrm{ND}$ & $\mathrm{ND}$ \\
\hline C16:0 & 20.97 & 24.58 \\
\hline C16:1 & 1.25 & ND \\
\hline C17:0 & 0.30 & 0.30 \\
\hline C17:1 & ND & ND \\
\hline C18:0 & 6.92 & 11.29 \\
\hline $\mathrm{C} 18: \ln 9 \mathrm{c}+\mathrm{t}(n-9)$ & 8.30 & 3.67 \\
\hline C18:2n6c $(n-6)$ & 38.64 & 43.42 \\
\hline C18:2n6t $(n-6)$ & ND & $\mathrm{ND}$ \\
\hline C18:3n6 (n-6) & 8.27 & 6.96 \\
\hline $\mathrm{C} 18: 3 \mathrm{n} 3(n-3)$ & 0.57 & 0.58 \\
\hline $\mathrm{C} 20: 0$ & 2.44 & 1.01 \\
\hline $\mathrm{C} 20: \ln 9$ & ND & 0.23 \\
\hline $\mathrm{C} 20: 2$ & ND & $\mathrm{ND}$ \\
\hline$C 20: 3 n 6(n-6)$ & ND & ND \\
\hline $\mathrm{C} 20: 3 \mathrm{n} 3(n-3)$ & ND & $\mathrm{ND}$ \\
\hline$C 20: 4 n 6(n-6)$ & 0.36 & $\mathrm{ND}$ \\
\hline $\mathrm{C} 20: 5 \mathrm{n} 3(n-3)$ & 3.35 & 2.62 \\
\hline $\mathrm{C} 22: 0$ & ND & $\mathrm{ND}$ \\
\hline $\mathrm{C} 22: \ln 9$ & 5.86 & 1.28 \\
\hline $\mathrm{C} 22: 2$ & ND & 0.88 \\
\hline $\mathrm{C} 23: 0$ & ND & $\mathrm{ND}$ \\
\hline $\mathrm{C} 22: 6 \mathrm{n} 3(n-3)$ & ND & ND \\
\hline $\mathrm{C} 24$ & ND & $\mathrm{ND}$ \\
\hline $\mathrm{C} 24: \ln 9$ & ND & $\mathrm{ND}$ \\
\hline Unsturated (UNSAT) & 66.61 & 59.64 \\
\hline Saturated (SAT) & 33.39 & 40.36 \\
\hline UNSAT/SAT & 1.99 & 1.48 \\
\hline$\Sigma$ Sat & 33.39 & 40.36 \\
\hline$\Sigma$ MUFA & 15.41 & 5.18 \\
\hline$\Sigma$ PUFA & 51.20 & 54.46 \\
\hline
\end{tabular}

ND: Not Dedected, MUFA: Mono unusaturated fatty acid, PUFA: Poli unusaturated fatty acid 
When the amount of unsaturated fatty acid was found to be higher in AT compared to AS, saturated fatty acid content was very low at AT compared to AS. At the same time omega fatty acid contents of the extracts were also determined and were given in Table 5.

Tablo 5. The $\omega-3, \omega-6$ and $\omega-9$ fatty acid contents of Allium tuncelianum and Allium sativum $\mathrm{L}$. and the comparison of total omega fatty acids

\begin{tabular}{|c|c|c|c|c|}
\hline$\omega-\mathbf{3}$ Fatty acid & C18:3n3 (n-3) & $\mathrm{C} 20: 3 \mathrm{n} 3(\mathrm{n}-3)$ & $\mathrm{C} 20: 5 \mathrm{n} 3(\mathrm{n}-3)$ & $C 22: 6 n 3(n-3)$ \\
\hline Allium tuncelianum & 0.57 & ND & 3.35 & ND \\
\hline Allium sativum L. & 0.58 & ND & 2.62 & ND \\
\hline$\omega-6$ Fatty acid & C18:2n6c(n-6) & C18:3n6 (n-6) & C20:3n6 (n-6) & C20:4n6 (n-6) \\
\hline Allium tuncelianum & 38.64 & 8.27 & ND & 0.36 \\
\hline Allium sativum L. & 43.42 & 6.96 & ND & ND \\
\hline$\omega-9$ Fatty acid & $C 18: 1 n 9 c+t(n-9)$ & C20:1n9 & C22:1n9 & C24:1n9 \\
\hline Allium tuncelianum & 8.30 & ND & 5.86 & ND \\
\hline Allium sativum L. & 3.67 & 0.23 & 1.28 & ND \\
\hline Fatty acids & Total $\omega-3$ & Total $\omega-6$ & Total $\omega-9$ & \\
\hline Allium tuncelianum & 3.92 & 46.91 & 14.16 & \\
\hline Allium sativum L. & 3.20 & 50.37 & 5.18 & \\
\hline
\end{tabular}

ND: Not detected

The essential fat acids are used in the formation of hormone-like compounds called prostaglandins. Prostaglandins regulate inflammation reactions linked to blood pressure, blood coagulation, blood lipid levels, immunity and infections. The role of saturated fats and fat acids in cardiovascular diseases is great. When unsaturated fat acids are added to the diet, this risk reduces. When the rates contained in AT are investigated, the saturated fat acid percentage is much lower than AS, so adding AT to the diet may lead to very positive results in terms of treatment. Some fat acids required by the body but only obtained externally, especially omega fat acid groups, are very important in terms of cardiovascular health. Omega 3 fatty acid has vital functions like aiding in protecting heart health in those with risk of cardiovascular disease or with the disease, slowing the formation of vein hardness, lowering triglyceride levels in blood, lowering the bad cholesterol (LDL) in heart disease, increasing the good cholesterol (HDL), and reducing the risk of stroke, second heart attack or death due to heart attack after a heart attack (Valentine and Valentine, 2004). Another essential fat acid with importance for brain activity is omega 6 . This fatty acid, considered to be effective in depression, is very important as absence in the brain is thought to cause different diseases. When the amounts of total omega 3 and total omega 9 are examined, it is seen that AT is richer in omega fatty acids than AS, while omega 6 fatty acids show no significant difference.

Amino acids are the basic building blocks of proteins. Essential amino acids are not synthesized at levels to meet needs in the human body, they must be obtained through nutritional intake. Cysteine, tyrosine, histidine and arginine are accepted as semi-essential amino acids in children because the metabolic reactions leading to their synthesis are not fully developed in children (Imura and Okada, 1998). When amino acid contents are assessed, the essential or non-essential amino acid amounts in AT are higher compared to $\mathrm{AS}$, which is one of the largest indicators that both in terms of antioxidant characteristics and other biological activities AT is more beneficial compared to AS. At the same time the amino acid contents of AS and AT were as given in Table 6 . 
Müşerref Hilal ŞEHITOĞLU et al.

Table 6. The amino acid contents of Allium tuncelianum and Allium sativum L. extracts

\begin{tabular}{|c|c|c|}
\hline Essential Amino acids (EAA) & Allium tuncelianum (gr/Kg) & Allium sativum L. (gr/Kg) \\
\hline Histidine (HIS) & 2.18 & 1.36 \\
\hline Isoleucine (ILE) & 1.84 & 1.32 \\
\hline Leucine (LEU) & 2.48 & 1.79 \\
\hline Lysine (LYS) & 3.95 & 2.82 \\
\hline Methionine (MET) & 0.34 & 0.25 \\
\hline Phenylalanine (PHE) & 2.13 & 1.43 \\
\hline Threonine (THR) & 2.93 & 2.25 \\
\hline Valine (VAL) & 2.77 & 1.86 \\
\hline \multicolumn{3}{|c|}{ Non-essential Amino acids (NEAA) } \\
\hline Alanine (ALA) & 94.31 & 111.27 \\
\hline Aspartic Acid (ASP) & 512.98 & 336.47 \\
\hline Glutamic Acid (GLU) & 382.74 & 210.33 \\
\hline Glycine (GLY) & 876.32 & 491.28 \\
\hline Serine (SER) & 6.70 & 4.19 \\
\hline Tyrosine (TYR) & 10.96 & 7.89 \\
\hline Cystine (C-C) & 0.00 & 0.00 \\
\hline Hydroxylysine (HLY) & 0.00 & 0.00 \\
\hline
\end{tabular}

In conclusion, when the antioxidant and antiradical activities and fat acid and amino acid contents of AT are assessed together, it appears it has stronger biological activity compared to AS. Selecting AT in diet will be very beneficial in terms of brain function, cancer-protective properties and as a precaution against cardiovascular diseases, especially.

\section{REFERENCES}

Ak T, Gülçin İ, 2008. Antioxidant and radical scavenging properties of curcumin. Chemico-Biological Interaction, 174: 27-37.

Altınışık M, 2000. Serbest oksijen radikalleri ve antioksidanlar. Adnan Menderes Üniversitesi, Tıp Fakültesi Biyokimya A.B.D. Aydın.

Ankri S, Mirelman D, 1999. Antimicrobial properties of allicin from garlic. Microbes and Infection, 1: 125-129.

Antony ML, Singh SV, 2011. Molecular mechanisms and targets of cancer chemoprevention by garlic-derived bioactive compound diallyl trisulfide. Indian Journal of Experimental Biology, 49: 805-816.

Apak R, Güçlü K, Özyürek M, Karademir SE, Erça E, 2006. The Cupric ion reducing antioxidant capacity and polyphenolic content of some herbal teas. International Journal of Food Science and Nutrition, 57: 292-304.

\section{TEŞEKKÜR}

This study was supported by Çanakkale Onsekiz Mart University Scientific Research Projects with project number FBA-2014-190.

Arrieta MP, Prats-Moya MS, 2012. Free amino acids and biogenic amines in Alicante Monastrell wines, Food Chemistry, 135: 1511-1519.

Buiatti E, Palli D, Blanchi S, Decarli A, Amadori D, Avellini C, Cipriani F, Cocco P, Giacosa A, Lorenzini L, Marubini E, Puntoni R, Saragoni A, Fraumeni J, Blot W, 1991. A casecontrol study of gastric cancer and diet in Italy. III, Risk patterns by histologic type. International Journal of Cancer, 48: 369-374.

Chi Z, Yan K, Gao L, Li J, Wang X, Wang, L, 2008. Diversity of marine yeasts with high protein content and evaluation of their nutritive compositions, Journal of the Marine Biological Association of the United Kingdom, 88: 1347-1352.

Davies KJA, 2000. Oxidative stress, antioxidant defenses, and damage removal, repair, and replacement systems. International Union of Biochemistry and Molecular Biology Life, 50: 279-289. 
Dizdaroğlu M, 1991. Chemical determination of free radicalinduced damage to DNA. Free Radical Biology and Medicine, 10: $225-242$.

Erickson MC, 1993. Lipid extraction from channel catfish muscle: comparison of solvent system. Journal of Food Science, 58: $84-89$.

Ertaş A, Boga M, Yilmaz MA, Yeşil Y, Tel G, Temel H, Hasimi N, Gazioğlu I, Ozturk M, Ugurlu P, 2015. A detailed study on the chemical and biological profile Thymus nummularius (Anzer tea): Rosmarinic acid. Industrial Corps and Products, 67: 336-345.

Fogliano V, Verde V, Randazzo G, Ritieni A, 1999. Method for measuring antioxidant activity and its application to monitoring the antioxidant capacity of wines. Journal of Agricultural and Food Chemistry, 47: 1035-1040.

Gülçin İ, 2009. Antioxidant activity of L-Adrenaline: An activitystructure insight. Chemico-Biological Interaction, 179: 71-80.

Gülçin İ, 2006. Antioxidant and antiradical activities of L-Carnitine. Life Sciences, 78: 803-811.

Gülçin İ, Mshvildadze V, Gepdiremen A, Elias R, 2004. Antioxidant activity of saponins isolated from ivy: $\alpha$-Hederin, hederasaponin- $\mathrm{C}$, hederacolchiside- $\mathrm{E}$ and hederacolchiside $\mathrm{F}$. Planta Medica, 70: 561-563.

Halliwell B, Gutteridge JMC, 1984. Oxygen toxicology, oxygen radicals, transition metals and disease. Biochemical Journal, 219: $1-4$.

Harborne JB, 1964. Biochemistry of phenolic compounds, Academic Press, 618, New York.

Haugaard N, 1968. Cellular mecanism of oxygen toxicity. Physology Review, 48: 311-373

Imura K, Okada A, 1998. Amino acid metabolism in pediatric patients. Nutrition, 14: 143-148.

International Union of Pure and Applied Chemistry (IUPAC), 1987. Standard Methods for the Analysis of Oils, Fats and Derivatives, 7th revised and enlarged ed., edited by C. Paquot and A. Hautfenne, Blackwell Scientific, London.

Kahkönen MP, Hopia AI, Vuorela HJ, Rauha JP, Pihlaja K, Kujala TS, Heinonen M, 1999. Antioxidant activity of plant extracts containing phenolic compounds. Journal of Agricaltural and Food Chemistry, 47: 3954-3962.

Lan H, Lu YY, 2004. Allitridi induces apoptosis by affecting Bcl2 expression and caspase- 3 activity in human gastric cancer cells. Acta Pharmacologica Sinica, 25: 219-225.

Loeckie L, De Zwart, John H, 1999. Biomarkers of free radical damage applications in expremental animals and in human. Free Radical Biology and Medicine, 26: 202-226.

Martin N, Bardisa L, Pantoja C, Vargas M, Quezada P, 1994. Antiarrhythmic profile of a garlic dialysate assayed in dogs and isolated atrial preparations. Journal of Ethnopharmacology, 43: $1-8$

Mei X, Lin X, Liu J, Lin X, Song P, Hu J, Liang X, 1989. The blocking of garlic on the formation of $\mathrm{N}$-nitrosoproline in humans. Acta Nutrimenta Sinica, 11: 141-145.

Mukherjee S, Lekli I, Goswami S, Das DK, 2009. Freshly crushed garlic is a superior cardioprotective agent than processed garlic. Journal of Agricultural and Food Chemistry, 57: 71377144.
Pacific RE, Davis KJA, 1991. Protein, lipit and DNA repair system in oxydative stress: the free radical theoryof aging revisited. Gerontology, 37: 166-180

Prior RL, Cao G, 2000. In vivo total antioxidant capacity: comparison of different analytical methods. Free Radical Biology and Medicine, 27: 1173-1181.

Rahman K, 2001. Historical perspective on garlic and cardiovascular disease. The Journal of Nutrition, 131: 977-979.

Re R, Pellegrini N, Proteggente A, Pannala A, Yang M, Rice-Evans C, 1999. Antioxidant activity applying an improved ABTS radical cation decolorization assay. Free Radical Biology and Medicine, 26: 1231-1237.

Ried K, Frank OR, Stocks NP, 2010. Aged garlic extract lowers blood pressure in patients with treated but uncontrolled hypertension: a randomised controlled trial. Maturitas, 67: 144-150.

Rivlin R, 2001. Historical perspective on the use of garlic. Journal of Nutrition, 131: 951-954.

Roginsky V, Lissi EA, 2005. Review of methods to determine chainbreaking antioxidant activity in food. Food Chemistry, 92: $235-254$

Seki T, Hosono T, Hosono-Fukao T, Inada K, Tanaka R, 2008. Anticancer effects of diallyl trisulfide derived from garlic. Asia Pacific Journal of Clinical Nutrition, 1: 249-252.

Sener G, Sakarcan A, Yegen BC, 2007. Role of garlic in the prevention of ischemia-reperfusion injury. Molecular Nutrition and Food Research, 51: 1345-1352.

Srivastava A, Hamre K, Stoss J, Chakrabarti R, Tonheim SK, 2006. Protein content and amino acid composition of the live feed rotifer (Brachionus plicatilis): With emphasis on the water soluble fraction. Aquaculture, 254: 534-543.

Steinmetz KA, Kushi LH, Bostick RM, Folson AR, Potter ID, 1994. Vegetables, fruit and colon cancer in the Iowa Women's Health Study. American Journal of Epidemiology, 39: 1-15.

Sumiyoshi H, Wargovich M, 1990. Chemoprevention of 1,2-dimethylhydrazine- induced colon cancer in mice by naturally occurring organosulfur compounds. Cancer Research. 50: 5084-5087.

Valentine RC, Valentine DL, 2004. Omega-3 fatty acids in cellular membranes: a unified concept. Progress in Lipid Research, 43: $383-402$.

Xiao D, Li M, Herman-Antosiewicz A, Antosiewicz J, Xiao H, 2006. Diallyl trisulfide inhibits angiogenic features of human umbilical vein endothelial cells by causing Akt inactivation and down-regulation of VEGF and VEGF-R2. Nutrition and Cancer, 55: 94-107.

Yen GC, Chen HY, 1995. Antioxidant Activity of Various Tea Extracts in Relation to Their Antimutagenicity. Journal of Agricultural and Food Chemistry, 43: 27-32.

Zheng W, Blot WJ, Shu XO, Gao YT, Ji BT, Ziegler RG, Fraumeni FJr, 1992. Diet and other risk factors for laryngeal cancer in Shanghai, China. American Journal of Epidemiology, 13: 178191 ,

Zhishen J, Mengcheng T, Jianming W, 1999. The determination of flavonoid contents on mulberry and their scavenging effects on superoxide radical. Food Chemistry, 64: 555-559. 